\title{
Conservation and Development Guidelines of the Historic Green Structure of Duke Jacob's Canal
}

\author{
Aija Ziemeḷniece, Latvia University of Agriculture
}

\begin{abstract}
The western and northern parts of the historic center of Jelgava forms a landscape in which there is preserved evidence of cultural and historical objects representing different centuries. The identification, restoration and preservation make it possible for the town to recover identity of its landscape space. The research includes analysis of the former Duke Jacob's canal with the prewar and current structure of the buildings and the green planting zones, partially restoring the historical bed of the watercourse. The rows of trees along the canal, the green slopes of the banks and the pedestrian bridges until the $30 \mathrm{~s}$ of the $20^{\text {th }}$ century brought in the town's dense building an aesthetically high-quality green space for recreation.
\end{abstract}

KEYWORDS: cultural-historic landscape, nature base, sightlines, urban landscape space.

The urban structure has been created over several centuries and shaped by different societies. It is built not only to meet the practical needs but also the social and aesthetic requirements [1]. The aesthetic quality of the environment is evaluated based on two key elements:

- the formal properties, which focus on the physical characteristics and how they contribute to the aesthetic response (scale, shape, contrast, etc.);

- symbolic or associative properties view factors that through the experience create connotations (identity, laconism, etc.) [1].

The urban constructional space is formed by the western and northern parts of the historic centre of Jelgava town with the survived testimony of both the human plans to transform nature and objects in the historical and cultural context describing different centuries. Maintenance of the urban identity, primarily, is associated with identification, restoration and conservation of objects in the cultural and landscape context, as well as a thorough care and protection of the landscape space characteristic of this site.

Preservation and development of the cultural and historical heritage of Jelgava town is included in the spatial planning documents of the town, where one of the key aspects is to recover the urban green veins, which were vividly expressed in the prewar years.

The purpose of the article is related to evaluation of the proposal of the green plantation renewal and a more detailed study of the urban housing in the western and the northern parts.

The town's historic centre as a monument of the urban construction protection contains areas of a number of old housing blocks, where only a few buildings survived as the town burned down during the war. Losing huge building areas, each of the old buildings that has escaped from falling to pieces, today is of a particular importance. The same is true for the green zones as in the post-war years with a change in the structure of the buildings the green network of the urban space has also changed. One of the "blue-green" structure elements was Duke Jacob's Canal, which was built in 1605 . Its bed connected the Svête River with the Driksa River and provided the town with a safe drinking water [7]. In the summer, it was a favourite esplanade for the townsfolk. The canal was filled up in the 30 s of the 20th century.

One of the most important landscape spaces of the town was Jacob's Canal, which started at the Gintermuiža Park in the western part and its length to the town rampart was around 1500 $\mathrm{m}$. At this section, there were meadows and pastures, but at the town rampart on its banks there were dense residential wooden buildings with gardens. The mouth of the canal was outlined by the picturesque flood-land meadows of the Svête River, which were especially impressive in the spring when the yellow willows, marsh marigolds and bird-cherries were in bloom. The historic and cultural landscape has survived to this day as in the spring flood waters of the river fill the entire flood-land, which prevents appearance of new buildings.

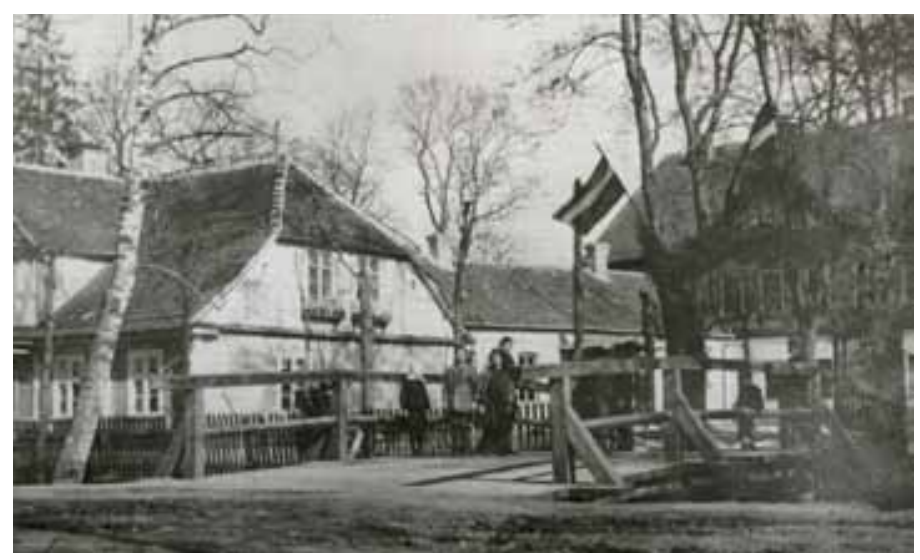

Fig. 1. The historical building along Duke Jacob's Canal (the 30s of the 20th century).

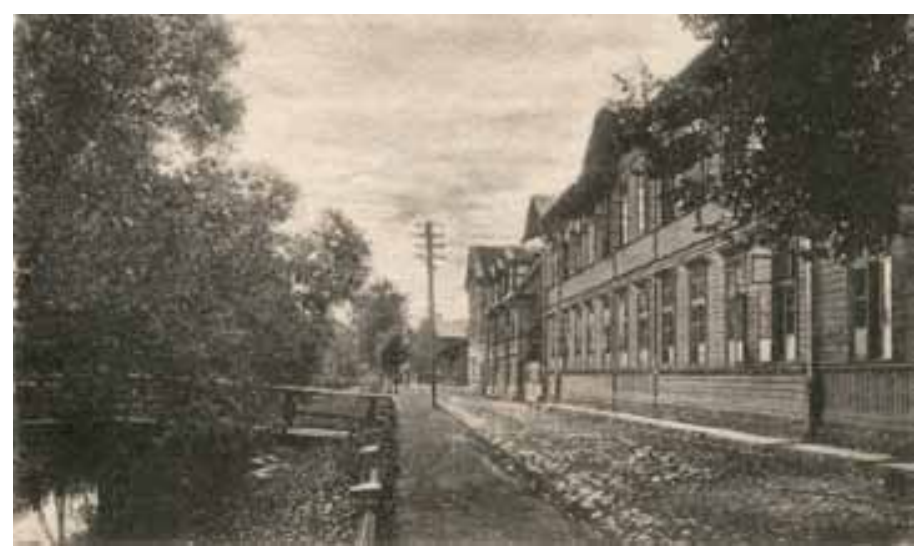

Fig. 2. Greenery of the canal embankment with a walking area and road (the $30 \mathrm{~s}$ of the 20th century). 


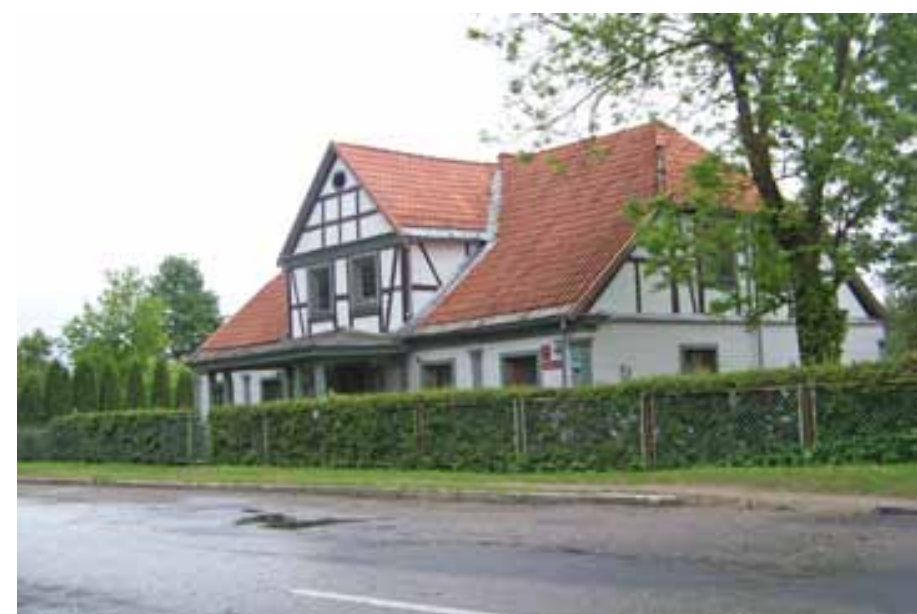

Fig. 3.The restored residential house at Dambja iela 17.

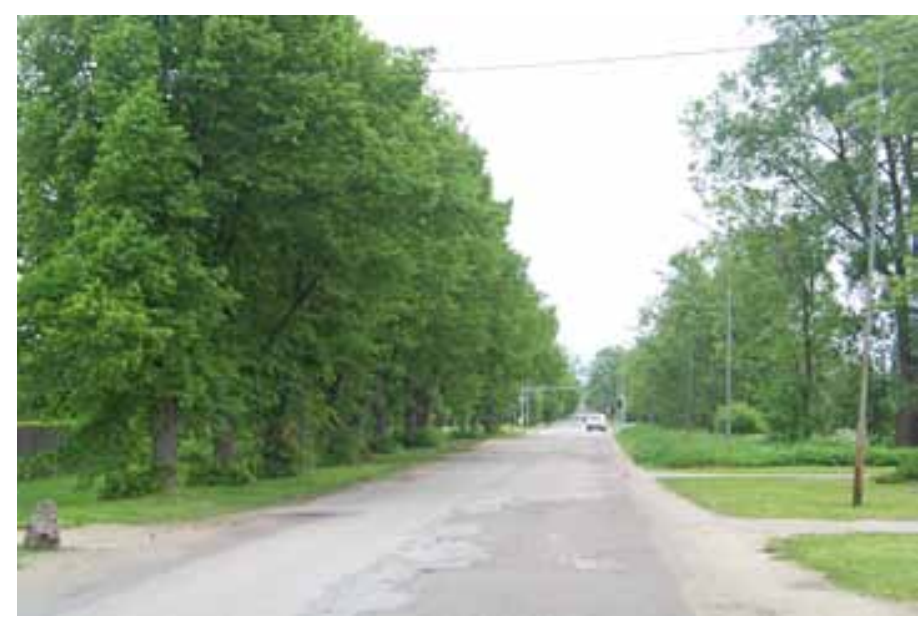

Fig. 4. The filled up canal place with a dense line of trees in Dambja iela (2012, author's photo).

Next to the flood-land there is the park of Old Gintermuiža with buildings. The park's area is occupied by a landscape area, which is $400 \mathrm{~m}$ long, the north-western part of which along the canal banks today is gone. In the 80 s of the 20th century, at this location about $200 \mathrm{~m}$ in length there was forming a new individual building area connecting the low-density housing estate of the 90 s of the 19th century. Thus, a continuous one-piece landscape has been obtained that continues or extends the historical area. In the park of Gintermuiža, there are separate groups of old trees that are adjacent to the right bank of the former canal to form against the longitudinal axis of the canal perpendicular green view spaces. They feature the separately placed historical 2-storey wooden buildings (the 10s, 20s of the 20th century). The manor area is enclosed by a stone fence, which is parallel to the longitudinal axis of the canal and rests $80 \mathrm{~m}$ from it. Clearing the view lines from the former canal location (shrub trimming, removal of tree seedlings, etc.), it is possible to recover a high-quality historical space, the expressiveness of which would also compliment restoration of the adjacent wooden buildings. In the view points from the canal location, the stone fence and the building of the old manor would be viewed. When restoring the canal bed in the area of the manor park, the carriageway of Dambja iela (street) should be built on the left bank of the canal so that the transport

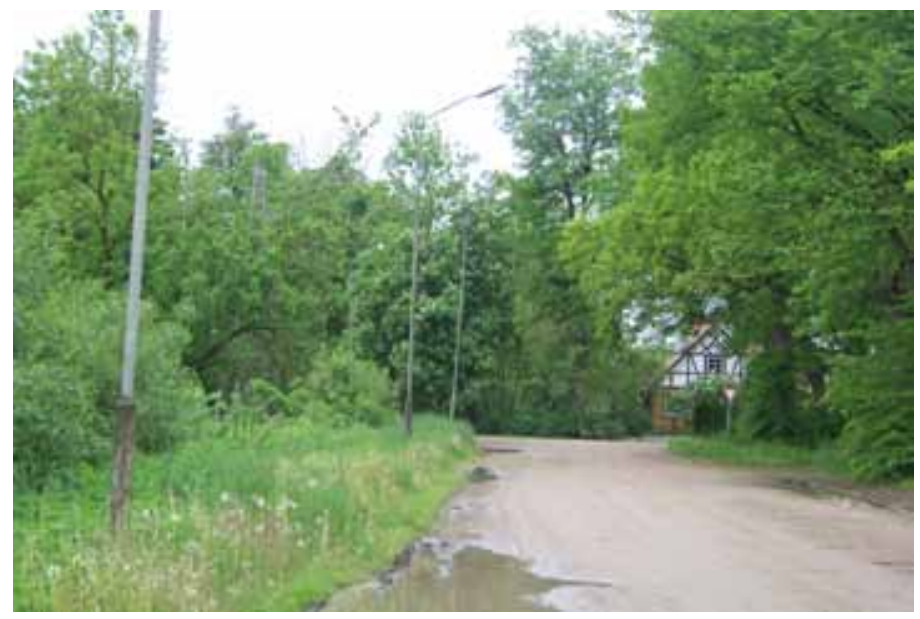

Fig. 5. The old canal starting at the park of Ģintermuiža (2012, author's photo).

zone does not split the watercourse from the park's landscapes. In the $60 \mathrm{~s}-70 \mathrm{~s}$ of the 20th century, constructing Dambja iela, the old trees were cut on the banks of the canal. If they were planed again, it would continue the historic pedestrian promenade up to the flood-land of the Svēte River. By recovering the manor landscape space with the canal, the western area of the urban environment would be supplemented by a new green wedge-type area.

In the northern part, the area of Gintermuiža is separated by the town's ring road, which in the $500 \mathrm{~m}$ section connects the residential high-rise area of the housing estate with the mansion area and the shopping centre (the northern-southern axis). In turn, the bed of the former canal (on the western-eastern axis) with the present tree lane would form the so-called green backbone, which connects to the side streets with lines of trees, gardens, etc.

It is possible to develop the continuation of the manor park area on the opposite side of the ring road, which is now a vast meadow, and designing it as Mežaparks, thus, extending the green wedge towards the centre of the town, which more convincingly would emphasise expressiveness of the cultural and historical landscape. Currently, the ring road cuts the historical green space and stops its seamless arrival into the urban environment. It is possible to build the ring road as a green ring, designing the roadlines of tree plantations and separate groups. It is based on the aspect that the ring road is placed very close to the town centre. In the perspective, the road transport load or intensity will increase several times as the arch branches with roads of an international significance leading to Lithuania, Riga, Liepaja. It is, therefore, necessary to reflect on the green planting line and the area, where one of the town's elements of the landscape space is the historic canal area.

In the direction of the town centre from the ring road to the town's rampart $(800 \mathrm{~m})$, the former canal bed (currently Dambja iela) is surrounded by the post-war mansion buildings with gardens and tree plantation lines. One of the historical houses of the canal embankment at Dambja iela 17 is restored (the 90 s of the 19th century), which vividly highlights the nature of buildings of the time gone by - as a filled framework building with wooden bearing walls and clay brick fill but the roof with clay tile covering. 


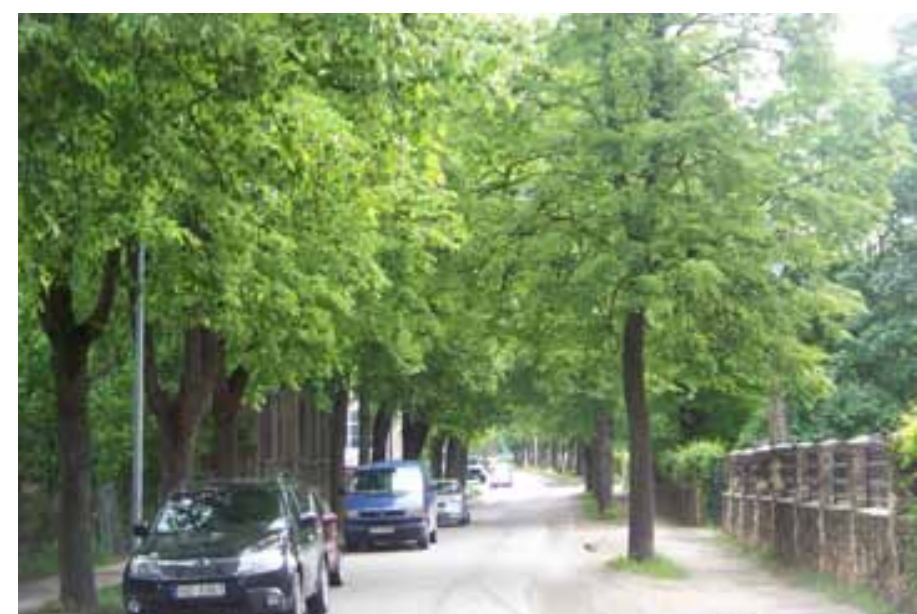

Fig. 6. The former canal place near the garden in Kr. Barona iela (2012, author's photo).

The old buildings and their scale along the canal can be seen in the small side-streets leading to the waterfront (Kungu iela 10, Kungu iela 12, etc.), where there were wooden strut framework buildings with gabled ridged roofs. The old historic downtown buildings were constructed in a low density configuration with beautiful apple-tree orchards around, which together with the canal plantations, formed a unified green landscape space. It was particularly scenic in the spring when the fruit trees and birdcherries were in bloom.

The buildings' height changed in the 30s of the 20th century with the construction of four 3-storey buildings by the canal for the needs of the Latvian army infantry regiment (300 m before the rampart place). In turn, in the 70 s of the 20 th century near here 5-storey and 3-storey buildings were constructed. The height disproportion of the existing buildings is successfully masked by a solid linden line. On the opposite side of the canal, wooden buildings of the beginning of the 20th century are preserved. In this place, the running of the canal reached the former place of the canal and formed an extension or the so-called pond, where traders from boats unloaded goods needed for the townsfolk. The pond size was sufficient for boats to dock and turn around. In this place, historically, the urban space created a number of small street splits: J. Asara - M. Dambja - Vecpilsētas - Dobeles Lielā - Kr. Barona iela, along which there were warehouses and small traders' shops. It forms the so-called western gate of the town. After World War I, the canal was gradually filled up in stages, starting from the Svete River side as in hot summer it dried out, its bed forming water drift decomposition.

Currently, instead of the pond there are crossroads of streets and a square, which marks another important green landscape space alongside the high-rise residential buildings. The square's place is a point, at which the longitudinal axis of Liela iela forms a rotation angle and there the distant lines can be viewed, where the street tree planting lines dominate, creating a green transport corridor of both the eastern and the western direction. Thanks to the street planting density (in the eastern part), there are architecturally expressionless forms of the post-war years (the 50s of the 20th century). Next to the square - the longitudinal axis of Liela iela and the traffic flow are divided by the green planting area, which even more clearly marks the former pond and the town's rampart place. As a vertical accent

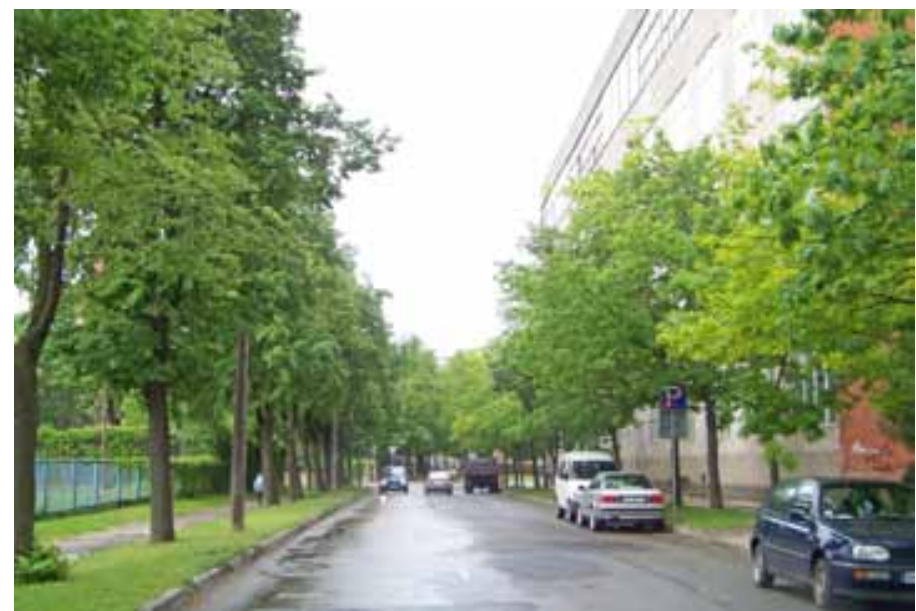

Fig. 7. The bed of the former canal with tree lines near the former Kramer's factory (2012, author's photo).

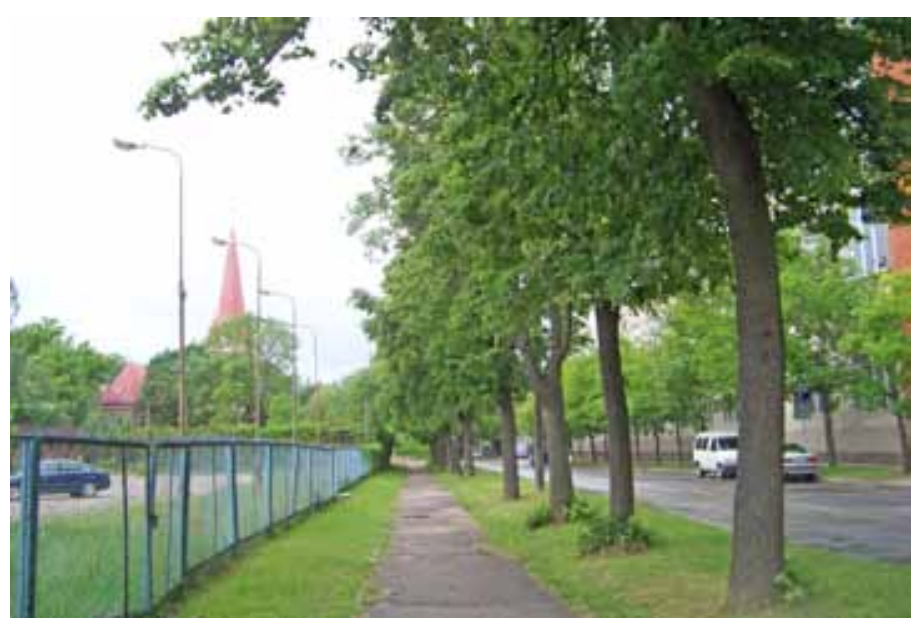

Fig. 8. The greenery of the former canal embankment in the view lines to St. Ann' Church (2012, author's photo).

in this view point there is the spire of St. Ann's Church next to it. The western part of the church garden or the left embankment of the former canal connects the downtown streets with the historic wooden buildings (the 90 s of the 19th century) - wooden framework buildings, where each building's plot of the backyard ends up with woodsheds. The street is not characterized by tree plantations but by wrought granite cobblestones.

The second parallel street that connects to the left promenade side of the former canal is Jāna Asara iela with wooden buildings and with a line of tree plantations of the post-war years. The buildings mark the line of the old rampart. Here a 400-yearold willow is also preserved with a thick canopy of leaves the branches of which suffer from the wind gusts every year. The height of the tree crown along J. Asara iela is now too wide, it hides the historical wooden buildings when entering the town from Dobele. In turn, the small lawn area (60 m wide) next to it should be used as a foreground marking the historical urban space. It is recommended that the separating tree plantations are placed in the area of the gasoline filling station, thus masking in the main view points the overwhelming vehicle area.

The landscape space of the former canal is also complemented by the narrow M. Dambja iela, which overlooks the romantic view of the spire of St. Anna's Church. 
From the former place of the town rampart, in the direction of the historic centre - the canal becomes a walking place or a promenade typical for the town recreation (the present Kr. Barona iela). Although, the town's rampart was considered the town's suburban area, however, there lived well-off people, who built there luxurious wooden architecture houses. Some of them have survived in Vecpilsētas iela No. 8, 10, 12 as witnesses of the late baroque period buildings.

At the former rampart of the town, there was the garden of St. Ann's Church, the greenery of which visually merged with greenery of the canal embankment. In this section, the watercourse was not filled during World War I. Besides, the photos show that the embankment of the canal was a popular walking area from the Latvian St. Ann's Church to the German Trinity Church.

The promenade of the canal embankment was decorated with linden tree plantations, small wooden bridges and the green slope of the embankment together with the buildings created a romantic urban space. Currently, the church garden and the linden plantations of the former canal remain. The canal created a distinctive urban "green-blue backbone". Currently, the old riverbed site connects to the perpendicular street tree plantation lines (Jaunatnes iela, Pasta iela, Mātera iela) and the high-rise residential backyard tree plantation groups.

Looking at the historic canal bed in its full length and including it in the urban area development concept, the canal landscape space has to be broken down into a number of green areas:

- the mouth area of the former canal near the flood-land meadows of the Svēte River;

- the cultural landscape space (Ģintermuiža parkland);

- the section of the former watercourse near the present town's ring road - the meadow landscape with long landscape lines to the historical Ģintermuiža Park;

- the landscape space of the south-western part of the canal consisting of the side-street connections with gardens (Kungu iela, Egas iela, Skolotāju iela, J. Asara iela);

- the tree lane of the canal promenade (Kr. Barona iela) and the garden context of St. Ann's Church in the structure of the rural buildings;

- the greenery area of the canal embankment along the industrial heritage and the green area of the backyards of the high-rise residential blocks of houses (from Jaunatnes iela to Pasta iela);

- the greenery areas of the square of the House of Culture and the central square (from Pasta iela up to Uzvaras iela).

Inclusion of the above-mentioned green landscape space in the rural environment is also important if in the coming decade the canal bed is not renewed.

Prof. Ivars Strautmanis has defined the fundamental architectural and environmental coexistence options:

- integration - a particular landscape is not destroyed but rather transformed so that interaction with the new spatial structures achieves a higher degree of the harmonic unity;

- subordination - when the given landscape components are formally subject to the new buildings' structural peculiarities;

- integration - integrating all the major factors of the rural buildings [2].
The expressiveness of the canal is also emphasized by the Old Market Square with perimeter buildings. The canal ended with a pool in the square, which visually supplemented the compositional expressiveness of the urban space. The tree plantations in the square were located only at the Town Hall, so laying emphasis on the town's main line of the buildings in the square.

The transformation process of the urban environment is affected by the disappearance of the historical area of buildings during the war years, and in its place in the 60s of the 20th century about 60 trees were planted. They have already reached the scale of the branches, and therefore a disproportion is created with the adjacent buildings. In particular, this applies to the groups of birch-trees. The historic square has also changed the vertical mark of the height obtained by levelling the building ruins in 1945 . The green square in the town centre still retains a temporary nature. Reconstruction of the centre was not possible up to the 90 s of the 20th century. In turn, now there are organized idea contests of the young architects, searching for a synthesis between the historical building space scale including the existing square greenery. Some of the architects' ideas include the restoration idea of the historic canal and basin in the square. The reconstruction projects also consider the existing tree plantation groups between the historic square and the canal intake in the Driksa River. At present, there are garages, the removal of which would give an opportunity to develop the green recreational space, which would connect to the Driksa Promenade.

The tree plantation lines of Duke Jacob's Canal and river embankment as a kind of the "green-blue fingers" brought veins to the town which, together with the buildings, created a picturesque street landscape silhouette view lines from the bridge and the garden of the palace [3]. At present, the reconstruction project of the Driksa Promenade is carried out by replacing the old trees with a new greenery and by strengthening the left bank slope and creating a number of recreation areas. In turn, for the renewal of the bed of Duke Jacob's Canal and the tree plantations, a number of sketch designs have been developed, which are included in the further development of the urban space.

Breaking down the town rampart at the beginning of the $19^{\text {th }}$ century, on the left side of Duke Jacob's Canal, a new functional zone - the industrial area - was created (the Kramer's metal factory and leather processing unit) [4]. Geographically, this place was located in the western part of the town, from which the trade route lead to the ice-free port of Liepaja. The construction volume was sufficiently distanced from St. Ann's Church and they did not compete spatially with the church.

In contrast, in the post-war years (the 70s of the 20th century), in developing the production, the factory got a huge building height, which disrupted scale and proportion of the historical space. The tree plantations along St. Ann's Church (Kr. Barona iela) were unable to mask massiveness of the 150-m-long building volume. In turn, the old church garden trees in the southern side of the church with the huge canopy of leaves screened the facades of the church at the side of Liela iela. The planted trees around 1970 in Jaunatnes iela have reached a great height at present, in its pedestrian zone the view lines on the factory building volume hide behind the green foliage. 
The other craft centre of the industrial heritage (approx. $100 \mathrm{~m}$ from Jacob's Canal) - built in the 90s of the 19th - has saved the compositional expressiveness of the 2-storey brick architecture and as a cultural heritage fits well into the urban environment. The area, historically, did not have tree plantations as it stood just outside the city walls in the pasture meadows. Currently, there are less dense buildings without specific lines of street tree plantings.

With the development of production areas along the canal bed, small workers' residential developments also arose. Mostly, they were 1-2-storey wooden buildings along Ausekḷa, Kazarmes, M. Dambja, J. Asara, Kārḷa and Lapskalna streets [5]. The streets were narrow as only two horse carts could exchange. None of the streets had tree plantations. In turn, in the backyards of the houses, there were household buildings with a small garden. Factory workers' houses concentrated in the northern part of the town, which relatively, according to the height marks, was a lower and wetter place, and flood waters stayed there the longest time [6].

In the post-war years, with the changes in the street network of the central part of the town and creation for it new tree plantations in the 50 s, 60 s of the 20th century, the main town landscape designer Jānis Liepin̄̌s successfully masked the impersonal standard building architecture in Lielā iela, Rīgas iela, Pasta iela, etc. Comparing the town's main transport motorways - Dobeles iela and Lithuanian Highway - with Dambja iela (the former bed place of the canal), it can be concluded that the historical canal greenery street is the most expressive and picturesque.

City Council of Jelgava, organizing workshops and competitions, has managed to come to a number of conclusions about Duke Jacob's Canal reconstruction proposals, offering to expose the canal bed fragmentary in separate stages:

- in three or four locations along the bed of Dambja iela, creating walking zones and pedestrian bridges;

- near the garden of St. Ann's Church opposite Vecpilsētas iela, so enriching the town's part not only with street cafes, lounge terraces, street trading area and the restored wooden buildings but also bringing the canal charm with the embankment slopes, aquatic plants and small architectural forms;

- in the zone of the former market square, where the town's cultural events are held and wider gatherings for celebrations of the town;

- the intake of the canal into the Driksa River, using the water-level difference and creating a waterfall that in the Driksa Promenade area could enrich the urban space.

\section{Conclusions}

Any inhabited locality has its own physical structure and symbolic identity. Most often the urban space forms the town's uniqueness; therefore, great importance is given to the creation of aesthetical quality of the urban environment.

The town is a seamless and complex form, which, at the same time, is changing and chaotic. A ready system, structured in levels, is not characteristic of it. All the elements are arranged in a complex structure, which may be understood as individual local systems that are interrelated to some extent. Each part of the town has its own formal and symbolic properties and their perception changes when arriving from one part to another. Each element has information about its local context and the whole. The urban environment becomes a noticeable and recognizable place if it is designed clearly and understandably for the users so that they can give it their own meaning and connection to the surrounding.

In order to create integrity of an inhabited area, the aesthetical quality of spatial form is dependent on the scale of this shape. It also applies to the successful networks of the green structure in the urban environment (street plantings, squares, parks, mansion gardens, wedge-shaped forest park areas, etc.).

\section{REFERENCES}

1. Liepa-Zemeša, M. Pilsētas vizuālās viengabalain̄̄bas veidošanas nosacījumi. Arhitektūra un Pilsētplānošana (RTU Zinātniskie raksti : 10. sērija). Rīga: RTU, 2010, 4. sējums, 137.-140. lpp.

2. Strautmanis, I. Dialogs ar telpu. Rīga: Liesma, 1977. 136 lpp.

3. Grosmane, E. Jelgava; arhitektūras un mākslas virtuālā rekonstrukcija [CD]. Latvijas Mākslas akadēmijas Mākslas vēstures institūts, 2008.

4. Tomašūns, A. Jelgavas novada vēstures ainas. Jelgava: Izglītība, 1993. 122 lpp.

5. Jansons, G. Kurzemes pilsētu senās koka ēkas. Rīga: Zinātne, 1982. 162. 1pp.

6. Schlau, K. O. Mitau im 19. Jahrhundert : Leben und Wirken des Bürgermeisters Franz von Zuccalmaglio (1800-1873). Wedemark-Elze: Hirschheydt, 1995. S. 101-109.

7. Grosmane, E. Jelgavas pilsētbūvnieciskā struktūra: pacēlumi un kritumi. Senā Jelgava (sastādītāja Elita Grosmane). Rīga: Neputns, 2010. 33.-38. 1pp.

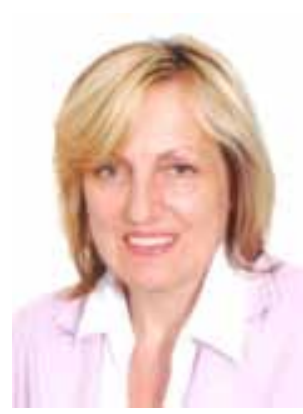

Aija Ziemeḷniece (born in 1955). Bachelor degree in architecture (1979). Master degree in science in pedagogy (1996). PhD degree in architectural science (1999), “Transformation Processes of Zemgale Rural Culture Landscape".

ARCHITECT, project office "Komunālprojekts" (since 1980, 3 Zemgales Avenue, Jelgava). ASSOCIATED PROFESSOR at the study programme "Landscape Architecture" of Latvia University of Agriculture (LLU, since 2000).

Publications: Lecture conspectus of the course "Landscape Development Problems" (LLU, 1998).

"The Visually Esthetical Quality of Landscape in Zemgale Plain" (RTU, 2009). "Transformation Processes in the Landscape of Cultural Heritage" (Saint-Petersburg, 2010).

Participation in architectural project competitions of state significance and winning the rights to elaborate technical projects: New building of Special Boarding School in Pelči (2001); Reconstruction of Dobele City High School (1997) and renovation of the primary school (2001); Sports hall in Grobina (2005); Reconstruction of the hospital "Gintermuiža" in Jelgava; Jelgava School No. 4; Reconstruction proposals of Čakstes Boulevard in Jelgava; Design proposals of St. Trinity church in Jelgava; Building of kindergarten in Jelgava.

Member of Latvian Society of Architects and Latvian Society of Landscape Architects.

\section{Contact Data}

Aija Ziemelniece

Latvia University of Agriculture

Address: Akadēmijas iela 19, Jelgava, LV-3001, Latvia

Phone: +371 29156945

E-mail: aija@k-projekts.lv 


\title{
Hercoga Jēkaba kanāla vēsturiskās zaḷās struktūras saglabāšanas un attīstības nostādnes
}

\author{
Aija Ziemeḷniece, Latvijas Lauksaimniecības universitāte
}

\author{
ATSLĒGAS VĀRDI: dabas pamatne, kultūrvēsturiskā ainava, \\ pilsētainaviskā telpa, skatu līnijas un punkti.
}

Pilsētas struktūra ir radīta vairāku gadsimtu garumā, un to veidojušas dažādas sabiedrības. Tā ir būvēta ne tikai lai apmierinātu praktiskās vajadzības, bet ar̄i sabiedriskās un estētiskās prasības [1]. Vides estētiskā kvalitāte tiek novērtēta, balstoties uz diviem pamatelementiem:

- formālās īpašības, kas fokusējas uz objekta fiziskajām pazīmēm, un kā tās veicina estētisko reakciju (mērogs, forma, kontrastainums utt.);

- simboliskās jeb asociatīvās īpašības apskata faktorus, kas caur pieredzi veido blakus nozīmes (identitāte, lakonisms utt.) [1].

Jelgavas vēsturiskā centra rietumu un ziemeḷu dalu veido pilsētbūvnieciskā telpa, kurā saglabājušās liecības gan par cilvēka iecerēm pārveidot dabu, gan dažādus gadsimtus raksturojoši kultūrvēsturiskie objekti. Pilsētas identitātes uzturēšana, galvenokārt, saistās ar kultūrainavisko objektu apzināšanu, atjaunošanu un saglabāšanu, kā arī šai vietai raksturīgās ainavtelpas rūpīgu kopšanu un aizsardzību.

Jelgavas pilsētas kultūrvēsturiskā mantojuma saglabāšana un attīstība ir ievērtēta pilsētas teritorijas plānojuma dokumentos, kur viens no galvenajiem aspektiem ir atgūt pilsētas zaḷo dzīslojumu, kas bija spilgti izteikts pirmskara gados.

Raksta mērkis ir saistīts ar zaḷo stādījumu atjaunošanas priekšlikumu izvērtējumu un detalizētāku izpēti pilsētas apbūves rietumu un ziemeļu daḷā.

Pilsētas vēsturiskais centrs kā pilsētbūvniecības aizsardzības piemineklis ietver vairāku veco apbūves kvartālu teritorijas, kurās ir saglabājušās tikai atsevišķas ēkas, jo pilsēta kara gados ir nodedzināta. Zaudējot milzīgas apbūves teritorijas, katrai no vecajām ēkām, kas paglābusies no posta, šodien ir īpaša nozīme. Tas pats ir attiecināms uz zaḷajām zonām, jo pēckara gados mainoties apbūves struktūrai, ir izmainījies arī pilsēttelpas zaḷais tīklojums. Viens no "zili zaḷās” struktūras elementiem bija Hercoga Jēkaba kanāls, kas bija izbūvēts 1605. gadā. Tā gultne savienoja Svētes upi ar Driksas upi, un nodrošināja pilsētu ar tîru dzeramo ūdeni Tas dod pilsētvidei ainaviski telpisko un vizuāli estētisko kvalitāti, un reizē pieškirot tai savu unikalitāti [7]. Vasarās tā bija pilsētnieku iemīllota promenādes vieta. Kanāls aizbērts 20. gs. trīsdesmitajos gados.

Jēkaba kanāls aizsākās pie Gintermuižas parka rietumu malas un tā garums līdz pilsētas valnim bija aptuveni 1500 m. Šajā posmā visapkārt kanālam atradās pḷavas un ganības, bet tuvāk pilsētas valnim tā krastos izvietojās blīva dzīvojamā apbūve ar dārziem. Līdz pilsētas valnim gar kanālu bija arī koku stādījumi. Galvenokārt tie bija vītoli, bērzi un liepas. Viens no vēsturiskajiem kanālmalas namiem Dambja ielā 17, kas celts
19. gs. devin,desmitajos gados, ir restaurēts. Šī pildrežǵa ēka ar nesošo koka karkasu un māla kieǵeḷu aizpildījumu, kā arī māla kārniniiem jumta iesegumā atspoguḷo tā laika apbūves raksturu.

Vecā apbūve un tās mērogs gar kanālu ir redzams arī mazajās šḳērsieliṇās, kas veda uz ūdensmalu (ēkas Kungu ielā 10, 12 u.c.). Tư atradās koka statṇu stāvbūves ar divslīpju jumtiem. Visus namus ietvēra ābeḷdārzi, kas kopā ar kanālmalas stādījumiem veidoja vienotu zaḷo ainavtelpu. Îpaši gleznaini šeit bija pavasarī, kad ziedēja auglu koki un ievas.

Pie bijušā vaḷna kanāls veidoja paplašinājumu jeb t.s. dīķa vietu, kur no laivām tika izkrautas preces pilsētnieku vajadzībām. Dīka lielums bija pietiekošs, lai laivas varētu gan piestāt, gan apgriezties. Šajā vietā pilsēttelpā ir vēsturiski izveidojies vairāku mazo ielinu - J. Asara, M. Dambja, Vecpilsētas, Dobeles, Lielās un Krišjāna Barona ielas sazarojums. Gar šīm ielām atradās preču noliktavas un nelielas sīktirgotavas. Te veidojās t.s. pilsētas rietumu vārti. Pēc pirmā pasaules kara kanāls, sākot no Svētes upes puses, tika pamazām pa aizbērts, jo karstās vasarās tam izžūstot, gultnē notika ūdens sanesumu pūšana.

No bijušo pilsētas valı̣u vietas vēsturiskā centra virzienā kanālam bija rekreācijai raksturīgā pastaigas zonas jeb promenādes loma. Lai gan pilsētas valn, skaitījās pilsētas mala, tomēr te dz̄̄voja situēti ḷaudis, izbūvējot greznus koka namus. Daži no tiem ir saglabājušies. Tie ir vēlīnā baroka būvniecības laika liecinieki Vecpilsētas ielā 8,10 un 12. Aiz bijušā pilsētas val,na atradās Annas baznīcas dārzs, kura stādījumi vizuāli saplūda ar kanālmalas stādījumiem. Ūdenstece šajā posmā vēl Pirmā pasaules kara laikā nebija aizbērta, un fotomateriāli liecina par kanālmalu kā populāru pastaigu zonu no latviskās Annas baznīcas līdz vāciskajai Trīsvienības baznīcai. Kanālmalas promenādi līdz ar stādījumiem greznoja koka tiltiṇi un zạ̄ā krasta nogāze. Kopā ar apbūvi tā veidoja romantisku pilsēttelpu. Patlaban šajā vietā ir saglabājies baznīcas dārzs. Atjaunoti arī bijušās kanālmalas liepu stādījumi.

Pilsētas teritorijas attīstības koncepcijā, ievērtējot vēsturisko kanāla vietu visā tās garumā, ainavtelpai var noteikt vairākas zalāas zonas:

- bijušo kanāla izteces kultūrainavas telpu (Ģintermuižas parka teritoriju);

- bijušo ūdensteces posmu pie Atmodas ielas, kas veido plavu ainavu ar garām skatu līnijam uz kultūrvēsturisko Ģintermuižas parku;

- kanāla dienvidrietumu daļas ainavtelpu, ko veido sānielinas ar dārziem tajās (Kungu iela, Egas iela, Skolotāju iela un J. Asara iela);

- kanāla promenādes aleju (Krišjāṇa Barona iela) un Annas baznīcas dārzu;

- kanālmalas stādījumus gar bijušo rūpniecības uzṇēmumu un daudzstāvu dzīvojamo kvartālu iekšpagalmiem (no Jaunatnes ielas līdz Pasta ielai); 
- kultūras nama skvēru un centrāāa laukuma apstādījumus (no Pasta ielas līdz Uzvaras ielai);

- kanāla ieteces Driksas upē vietu (daudzstāvu dzīvojamā kvartāla zal̦ā teritorija).

Zalı ainavtelpu ievērtējums pilsētvidē ir svarīgs arī gadījumā,ja tuvākajos desmit gados netiks veikta kanāla gultnes atjaunošana. Profesors Ivars Strautmanis ir definējis principiālus arhitektūras un apkārtējās vides koeksistences variantus:

- integrācija: konkrēta ainava netiek iznīcināta, bet gan pārveidota tā, lai mijiedarbībā ar jauno telpisko struktūru sasniegtu augstākas pakāpes harmonisko vienību;

- subordinācija: attiecīgās ainavas sastāvdaḷas formāli tiek pakḷautas jaunās apbūves struktūras īpatnībām;

- integrācija: telpā tiek integrēti visi būtiski svarīgākie pilsētbūvnieciskie faktori [2].

Kanāla izteiksmīgumu akcentēja arī vecais Tirgus laukums. Kara laikā zaudētās laukuma apbūves vietā 20. gs. sešdesmitajos gados ir iestādīti aptuveni 60 koki. Tie ir sasnieguši izmērus, kas veido disproporciju ar apkārtējo apbūvi. Īpaši tas ir attiecināms uz bērzu grupām. Pilsētas vēsturiskā centra daḷa bija plašs, ar akmens bruği iesegts laukums, kurā vienīgi liepu rinda gar laukuma austrumu malu rotāja Rātsnama ēku.

Hercoga Jēkaba kanālmalas pastaigu zona bija līdzīga netālajai Driksas upes krasta promenādei, kas veidoja nedaudz savādāku pilsētbūvnieciskās telpas mērogu. Abas promenādes satikās pie Tirgus laukuma. Kanālmalas un upes krasta koku stādījumu rindas kā savdabīgi „zalii-zilie pirksti” ienesa pilsētai dz̄̄slojumu, kas kopā ar apbūvi veidoja gleznainu pilsētainavas siluetu skatu līnijās no tilta [3]. Patlaban tiek realizēts Driksas promenādes atjaunošanas projekts, vecos kokus nomainot ar jauniem stādījumiem, kā ar̄̄ nostiprinot kreisā krasta nogāzi un izveidojot vairākas rekreācijas zonas. Savukārt Hercoga Jēkaba kanāla gultnes un koku stādījumu atjaunošanā ir izstrādāti vairāki skiču projekti, kas tiek ievērtēti tālākā pilsēttelpas attīstībā.

19. gs. sākumā, nojaucot pilsētas vaḷnus, hercoga Jēkaba kanāla kreisajā pusē attīstījās jauna funkcionālā zona - rūpniecības teritorija (Krāmera metāla fabrika un ādu pārstrādes ražotne) [4]. Šì vieta atradās pilsētas rietumu daḷā, no kuras veda tirdzniecības ceḷš uz neaizsalstošo Liepājas ostu. Ēkas bija pietiekoši tālu no Annas baznīcas un telpiski nekonkurēja ar dievnamu. 20. gs. septiņdesmitajos gados uzcēla milzīga augstuma ražošanas ēku. Tā izjauca konkrētās vēsturiskās telpas mērogu un proporcijas. Koku stādījumi gar Annas baznīcu (Kr. Barona ielā) nespēja slāpēt ap $150 \mathrm{~m}$ garā būvapjoma masivitāti. Savukārt vecie baznīcas dārza koki dienvidu pusē ar milzīgajiem vainagiem aizsedz dievnama fasādi Lielās ielas pusē. Ap 1970. gadu stādītie koki Jaunatnes ielā patlaban ir sasnieguši lielu augstumu un skatu līnijās no gājēju zonas paslēpj aiz zaḷajām lapotnēm vizuāli smagnējos rūpnīcas būvapjomus. Izvērtējot koku blīvumu un augstumu šajā ielas posmā, ir jāpārdomā baznīcas dārza un ielas stādījumu proporcijas.

Otrs industriālā mantojuma objekts ir bijušās ādu fabrika divstāvu ēkas, kas būvētas 19. gs. devindesmitajos gados un atrodas 100 m attālumā no Jēkaba kanāla kreisā krasta vietas. Tās saglabājušas kieǵel,u arhitektūras kompozicionālo izteiksmi un vizuāli labi iederas pilsētvidē. Teritorijā nav bijuši koku stādījumi, jo tā atradās plavās aiz pilsētas vaḷniem. Arī patlaban te ir retāka apbūve bez noteiktiem ielas apstādījumiem.
Attīstoties ražošanas teritorijām gar kanāla gultni, radās arī nelieli strādnieku dzīvojamie kvartāli. Galvenokārt tā bija viena vai divu stāvu koka apbūve gar Ausekḷa, Kazarmes, M. Dambja, J. Asara, Kārḷa un Lapskalna ielām [5]. Ieliņas bija šauras. Tajās varēja izmainīties tikai divi zirgu pajūgi. Nevienā no ielin̄ām nav bijuši koku stādījumi. Ēku iekšpagalmos atradās saimniecības ēkas un nelieli dārzi. Fabrikas strādnieku mājas koncentrējās pilsētas ziemeḷu daḷā. Tā bija zemāka un mitrāka vieta, un palu ūdeṇi tur turējās ilgāk [6].

Jelgavas pilsētas pašvaldībai, organizējot plenērus un konkursus, ir izdevies iegūt vairākus Hercoga Jēkaba kanāla rekonstrukcijas priekšlikumus:

- kanālu atsegt pa Dambja ielas garenasi, saglabājot transporta kustību un izbūvējot pastaigu un riteņbraucēju celiņus ar atpūtas zonām, bērnu laukumiem un gājēju tiltiniem;

- atjaunot kanāla gultni pie Annas baznīcas dārza iepretim Vecpilsētas ielai, tur izvietojot nelielu atpūtas laukumu ar strūklaku, kas simbolizē vēsturisko ielu sazarojuma vietu un kanāla paplašinājumu;

- atsegt kanālu bijušajā Tirgus laukuma zonā, kā arī pie ieteces Driksas upē.

\section{SECINĀJUMI}

Apdzīvotai vietai piemīt sava fiziskā struktūra un simboliskā identitāte. Pilsētvidei to īpaši spilgti dod zalie stādījumi, kuriem ir svarīga loma apdzīvotas vietas arhitektoniski kompozicionālās struktūras attīstībā. Tas dod pilsētvidei ainaviski telpisko un vizuāli estētisko kvalitāti, un reizē pieškirot tai savu unikalitāti.

Pilsēta ir viengabalaina un komplicēta forma, tajā pašā laikā mainīga un haotiska. Tai nav raksturīga visos līmeņos sakārtota struktūra. Pilsēttelpas elementi ir sakārtoti sarežğītā struktūrā, kuru veido atseviškas lokālas sistēmas, kas kompozicionāli ir savstarpēji saistītas. Pilsētvides kompozicionālās izteiksmes mainīgumu dod kokaugu un krūmu grupu dendroloǵiskās īpašības (krāsa, forma, augstums, uzziedēšanas laiks, smarža utt.).

Katrai pilsētas daḷai piemīt savas arhitektoniski kompozicionālās īpašības, kuru uztvere mainās, nonākot no vienas pilsētas daḷas otrā. Pilsēttelpa kḷūst par pamanāmu un atpaz̄istamu vietu, ja tā ir funkcionāli skaidri un harmoniski viegli uztverama tās lietotājiem, lai tie varētu pieškirt tai savu nozīmi un saikni ar apkārtni. Lai tiktu radīta pilsētas zaḷās veides harmoniska viengabalainība, telpiskās formas estētiskā kvalitāte ir atkarīga no noteiktas pilsētas vietas mēroga.

\section{ATTĒLI}

1. att. Vēsturiskā apbūve gar Hercoga Jēkaba kanālu (20. gs. trīsdesmito gadu foto).

2. att. Kanālmalas apstādījumi ar pastaigu zonu un brauktuvi (20. gs. trīsdesmito gadu foto).

3. att. Restaurētā dzīvojamā èka Dambja ielā 17 .

4. att. Aizbērtā kanāla vieta ar blīvu koku apauguma līniju Dambja ielā (2012, autora foto)

5. att. Vecā kanāla aizsākums pie G̣intermuižas parka (2012, autora foto). 6. att. Bijusī kanāla vieta pie baznīcas dārza Kr. Barona ielā (2012, autora foto)

7. att. Bijusī kanāla gultne ar koku rindām pie bij. Krāmera rūpnīcas (2012, autora foto).

8. att. Bijušie kanālmalas stādījumi skatu līnijās uz Annas baznīcu (2012, autora foto). 


\section{IZMANTOTIE AVOTI}

1. Liepa-Zemeša, M. Pilsētas vizuālās viengabalainības veidošanas nosacījumi. Arhitektūra un Pilsētplānošana (RTU Zinātniskie raksti : 10. sērija). Rīga: RTU, 2010, 4. sējums, 137.-140. lpp.

2. Strautmanis, I. Dialogs ar telpu. Rīga: Liesma, 1977. 136 lpp.

3. Grosmane, E. Jelgava; arhitektūras un mākslas virtuālā rekonstrukcija [CD]. Latvijas Mākslas akadēmijas Mākslas vēstures institūts, 2008.

4. Tomašūns, A. Jelgavas novada vēstures ainas. Jelgava: Izglītība, 1993. 122 lpp.

5. Jansons, G. Kurzemes pilsētu senās koka ēkas. Rīga: Zinātne, 1982. 162. lpp.

6. Schlau, K. O. Mitau im 19. Jahrhundert : Leben und Wirken des Bürgermeisters Franz von Zuccalmaglio (1800-1873). Wedemark-Elze: Hirschheydt, 1995. S. 101-109.

7. Grosmane, E. Jelgavas pilsētbūvnieciskā struktūra: pacēlumi un kritumi. Senā Jelgava (sastādītāja Elita Grosmane). Rīga: Neputns, 2010. 33.38. 1pp. 